\title{
ULTRASTRUCTURE OF RABBIT SYNOVIAL MEMBRANE
}

\author{
BY \\ F. N. GHADIALLY AND S. ROY \\ Department of Pathology, University of Sheffield
}

Recent electron microscopic studies of normal and pathological synovia have given a fresh insight into the structure and function of this tissue. The structure of human (Barland, Novikoff, and Hamerman, 1962; Roy, Ghadially, and Crane, 1966) and guinea-pig synovium (Wyllie, More, and Haust, 1964) has been studied in some detail, but only brief accounts of normal rabbit synovium can be found in papers dealing with the removal of injected substances from joints (Ball, Chapman, and Muirden, 1964; Cochrane, Davies, and Palfrey, 1965).

The rabbit is the largest common laboratory rodent and as such its knee joint has been the subject of much study and many experimental procedures. It is therefore necessary to study and record the ultrastructure of the synovium of this valuable experimental animal in some detail.

\section{Material and Methods}

Synovial membrane was collected from the knee joints of seven normal rabbits weighing between 1,600 and $2,000 \mathrm{~g}$. The animals were anaesthetized with ether. After cutting the suprapatellar tendon and reflecting the patella, a small piece of synovium measuring about $5 \times 3 \mathrm{~mm}$. was removed promptly from the infrapatellar region. The tissue was then placed on a piece of filter paper and dropped in buffered cold osmium (Palade, 1952). After fixation for 2 hours at $4^{\circ} \mathrm{C}$., the tissue was cut into thin strips about $1 \mathrm{~mm}$. wide. The synovial membrane with a minimum of subsynovial tissue was dissected off the filter paper leaving behind most of the collagenous and fatty tissue which would have interfered with the cutting of ultrathin sections. The synovial tissue was then processed according to the method of Glauert (1961) and orientated according to the method of Coulter (1962). Sections were cut with the Porter Blum microtome, mounted on uncoated copper grids, stained with lead citrate (Reynolds, 1963), and examined under the A.E.I. electron microscope using an accelerating $\frac{\omega}{\infty}$ voltage of 50 or $75 \mathrm{kV}$.

Another piece of synovium from the same joint of each animal was fixed in formalin and processed for light microscopy with haematoxylin and eosin stain.

\section{Results}

\section{Light Microscopy}

The lining cells of the normal rabbit synovium form a layer one to three cells thick. The cells are placed on fibro-fatty tissue except at the periphery of the joint cavity where the cells lie directly on vascular fibrous tissue with very little fat in it.

\section{Electron Microscopy}

The cells of the normal rabbit synovium are, as a rule, loosely arranged and form a discontinuous? outer layer (Figs 1 and 2, opposite). They are separated from each other by a moderately electron dense 0 matrix, the structure of which will be described later. Though most of the cells are separated from each other in this fashion, occasional cells are closely apposed. However, no desmosomes, tight junctions, or other connecting links could be demonstrated in 9 this region (Fig. 3, overleaf). Filopodia are only $D$ occasionally seen in normal rabbit synovial cells even in the most superficial layer. No basement mem- N brane can be detected between the synovial cells and the sub-synovial tissue (Fig. 2).

Synovial Cells.-Broadly speaking two types of cells can be identified in rabbit synovium somewhatco similar to those described in man by Barland and $\overparen{D}$ others (1962) and Roy and others (1966). Type A $\stackrel{\text { ? }}{?}$ cells show well-developed Golgi complexes, numerous smooth-walled vesicles but little rough endo- $\frac{O}{\Phi}$ plasmic reticulum (R.E.R.) (Fig. 4, overleaf). 


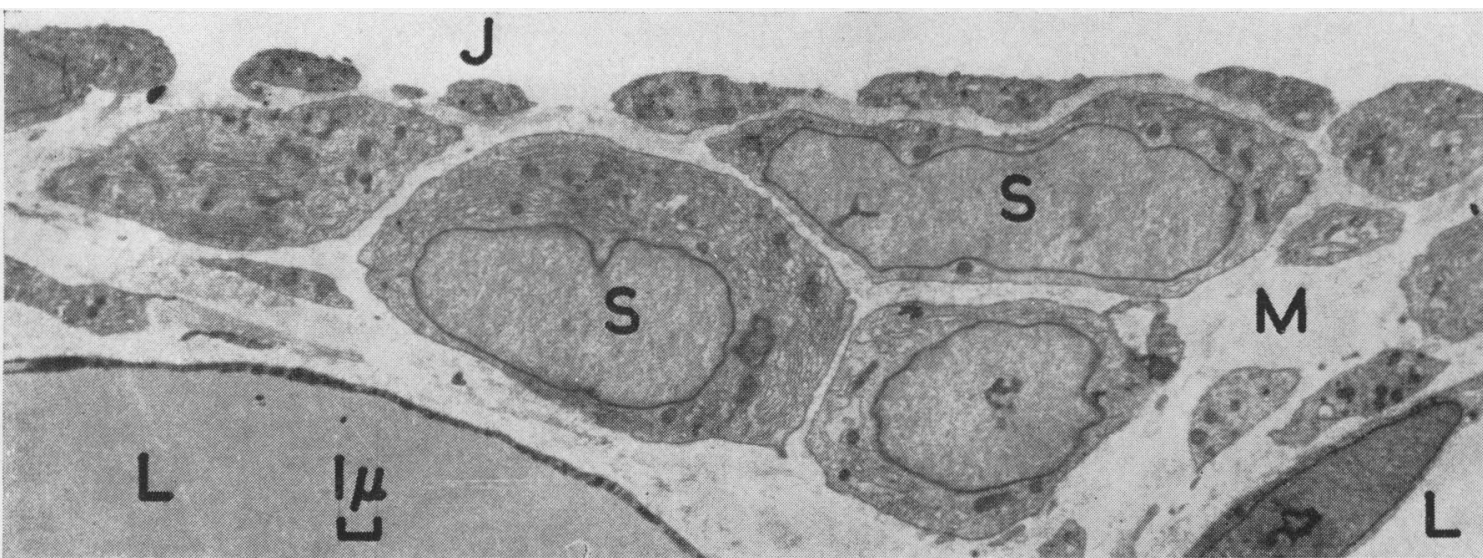

Fig. 1.-Low-power view of synovium, showing two sub-synovial lipocytes (L) and synovial cells (S) set in a medium density matrix $(M)$. Joint space $(\mathbf{J}) . \quad \times 3,500$.

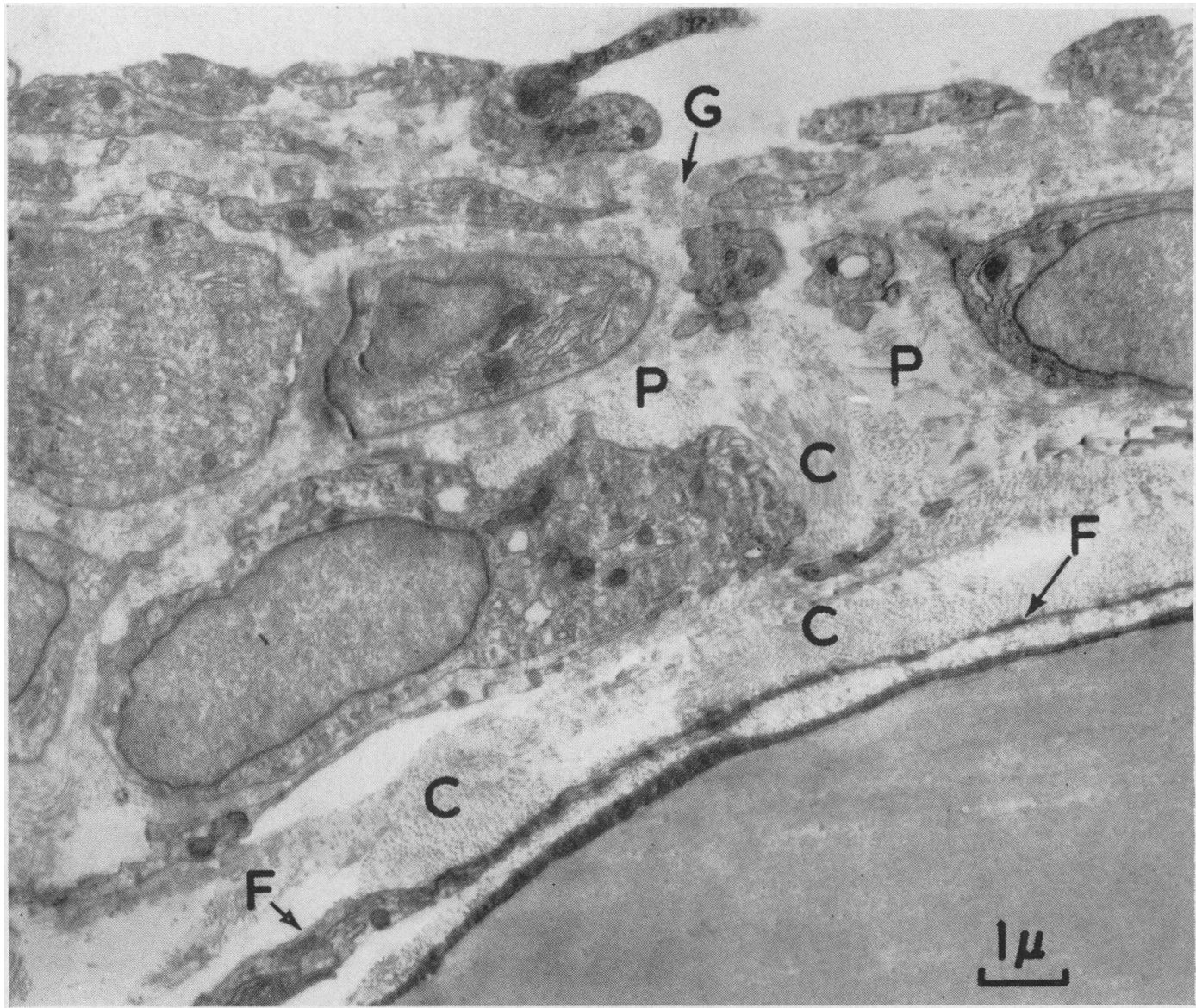

Fig. 2.-Loosely arranged synovial cells, showing discontinuous superficial layer. Note absence of basement membrane. Long processes of fibrocytes (F) and banded collagen (C) occur in the deep zone of matrix. Collagen and aperiodic fibres (P) Occur in the mid zone. Granular material $(G)$ can be seen in the superficial zone. $\times 9,000$. 


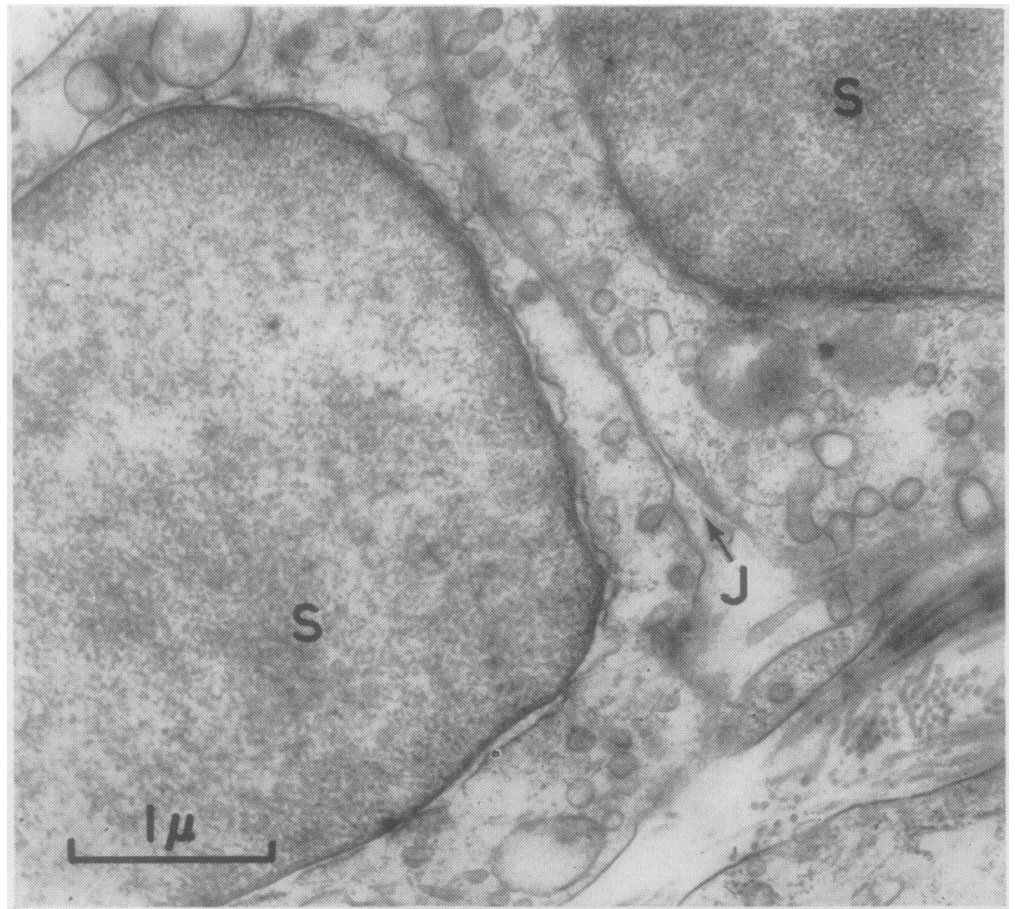


Type B cells are well endowed with R.E.R. but show only a few smooth-walled vesicles or Golgi complexes (Fig. 5). It must, however, be stressed that intermediate forms impossible to classify as Type A or B occur quite frequently.

The Golgi Complex shows many features of interest (Figs 4 and 6). Usually it is seen to be composed of elongated and circular sacs lying close together. Occasionally some of the sacs lying in the Golgi region are dilated and contain electron lucent material. In most instances, however, the smoothwalled vesicles in the Golgi and also in other parts of the cell contain some medium density material while at times electron opaque granules can also be identified within these vesicles.

Pinocytic Vesicles seem to occur more frequently in Type B cells (Figs 4 and 5). They contain कै material of low electron density and, in favourable situations, show continuity with the cell membrane.

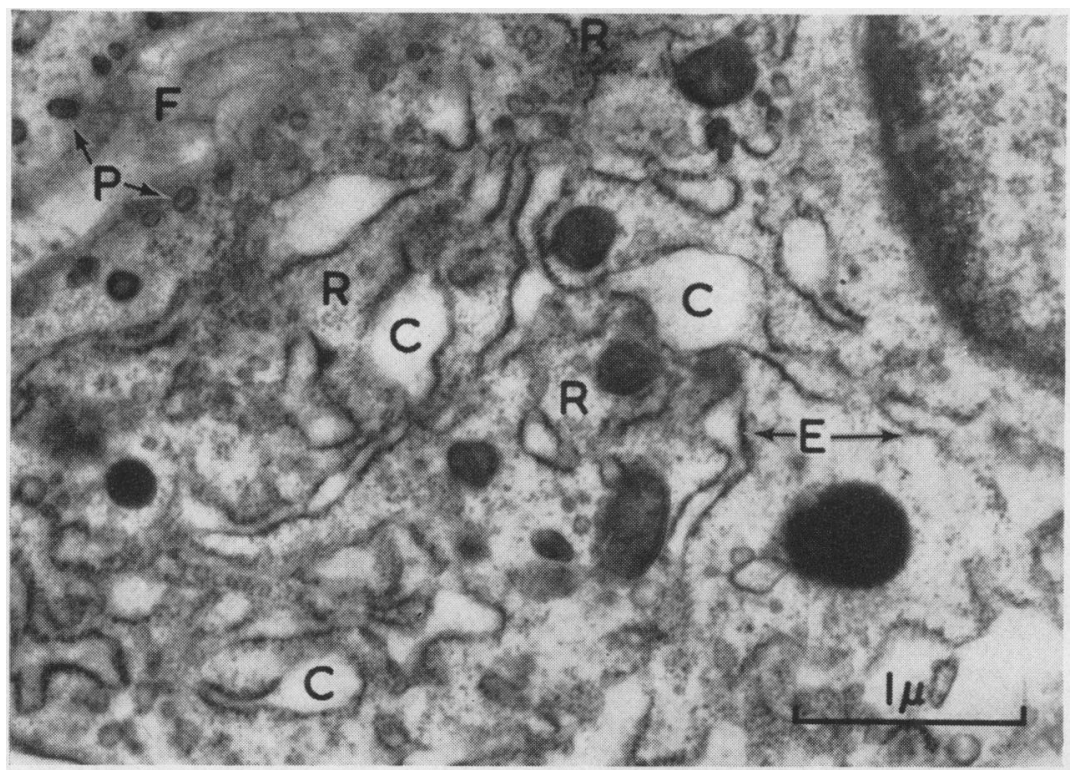

Fig. 5.-Type B cell, showing abundant rough endoplasmic reticulum (E), dilated cisternae (C), and free ribosomes ( $R$ ) Note numerous pinocytic vesicles (P) and aperiodic fibres (F) in adjacent matrix. $\times 24,000$.

Fig. 6.-Type A, cell showing Golgi complexes (G), mitochondria (M), filopodia (F), and intracellular filaments (I).

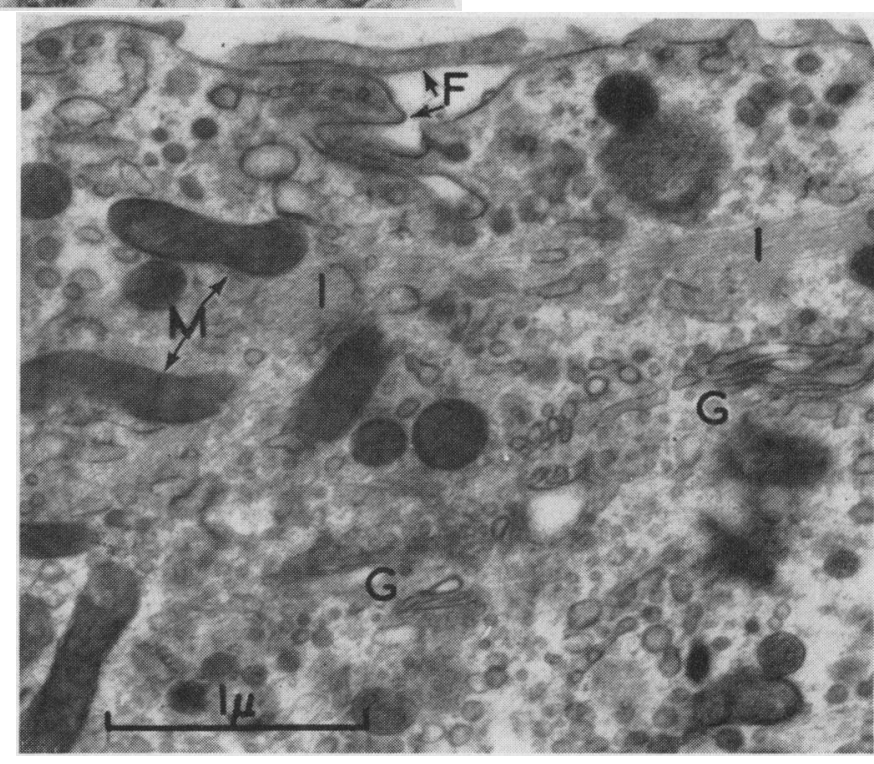
$\times 27,000$. 
R.E.R., found mainly in Type B cells, is seen to be arranged as long parallel membranes or as oval or circular sacs, similar to that seen in many cells elsewhere. In the normal synovium some degree of cisternal dilatation is frequently encountered. Ribonucleoprotein (RNP) particles are easily identified on the membrane and also as clumps lying free in the cytoplasm (Figs 3 and 5).

Both types of cells seem to be rather poorly endowed with mitochondria. They are morphologically similar to mitochondria seen elsewhere. Perhaps the only point worth noting is that most of them have an electron dense matrix (Figs 5 and 6 ) and the cristae are hence difficult to visualize.

Single membrane bound electron dense bodies morphologically similar to lysosomes seen elsewhere were occasionally found in both Type A and B cells (Fig. 7).

Intracellular fine filaments are rarely encountered in normal rabbit synovium (Fig. 6).

Matrix.-As mentioned earlier the synovial cells lie in a medium density matrix (Fig. 2). Periodically banded collagen fibres can be found in the deep zone of the synovium and also at times between the synovial cells in the middle zone (Fig. 8), but we have not found them in the superficial zone adjoin-

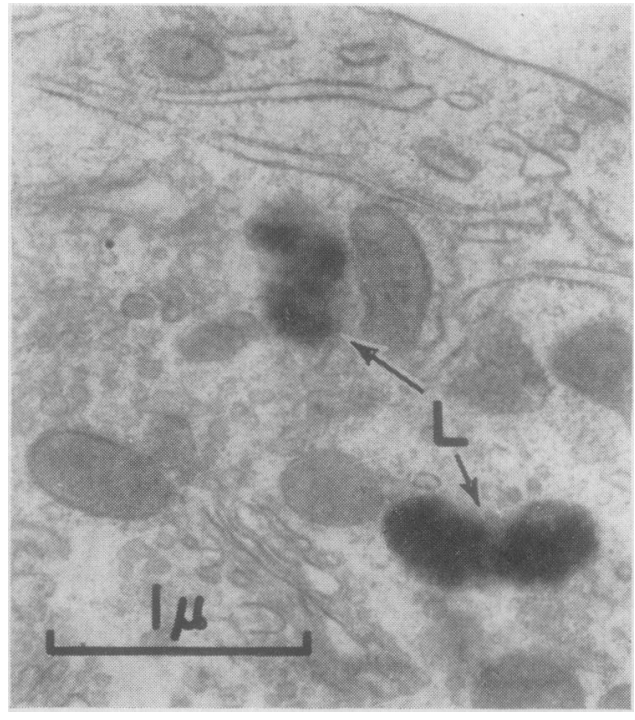

Fig. 7.-Lysosomes $(L)$ in synovial cell. $\times 26,000$.

ing the joint space. Many aperiodic fibres also occur in the matrix. These, however, reside in the middle and superficial zones of the synovium. The aperiodic fibres are as a rule slimmer and shorter than

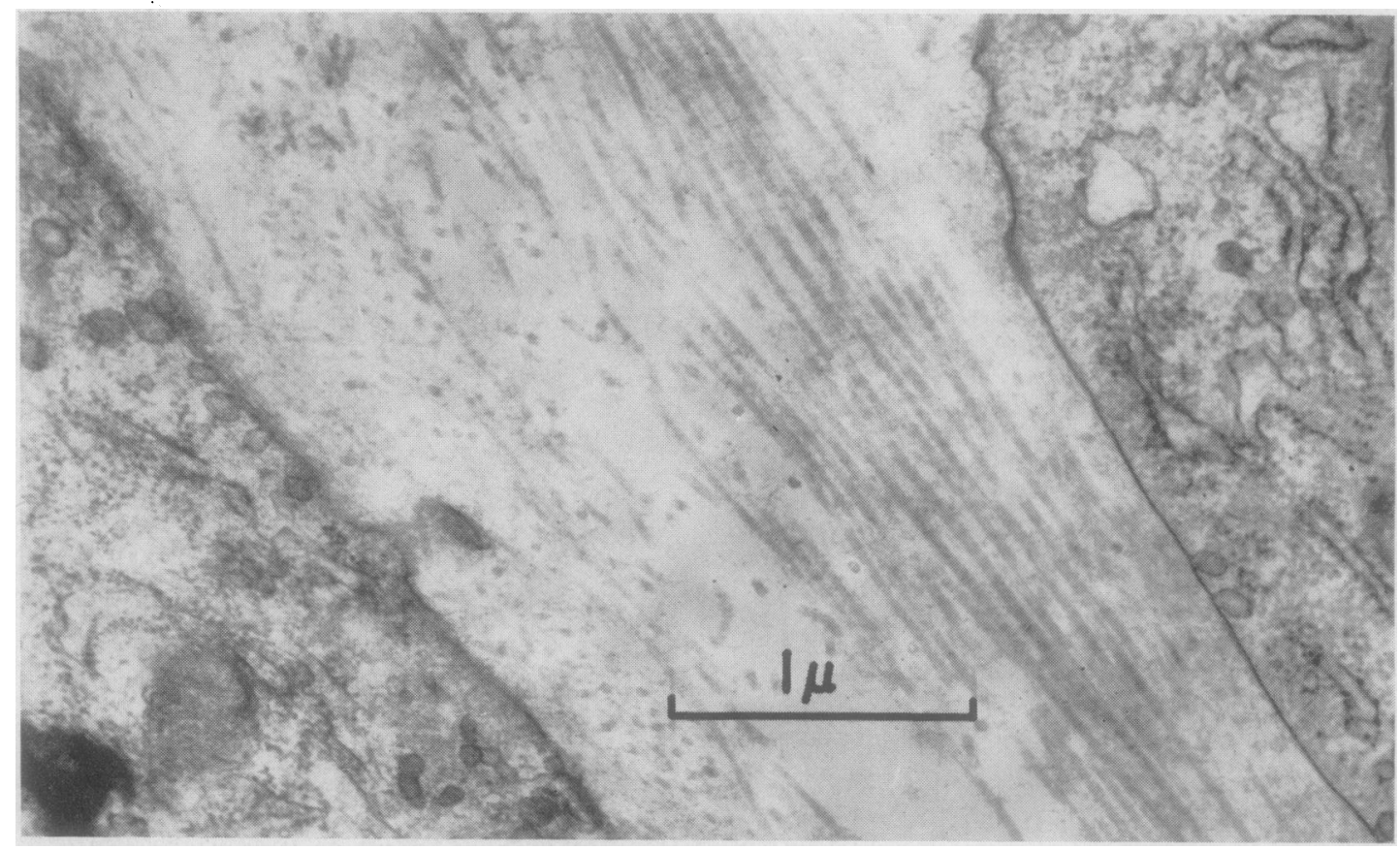

Fig. 8. - Periodically banded collagen fibres lying between two cells in the middle zone. $\quad \times 32,000$. 


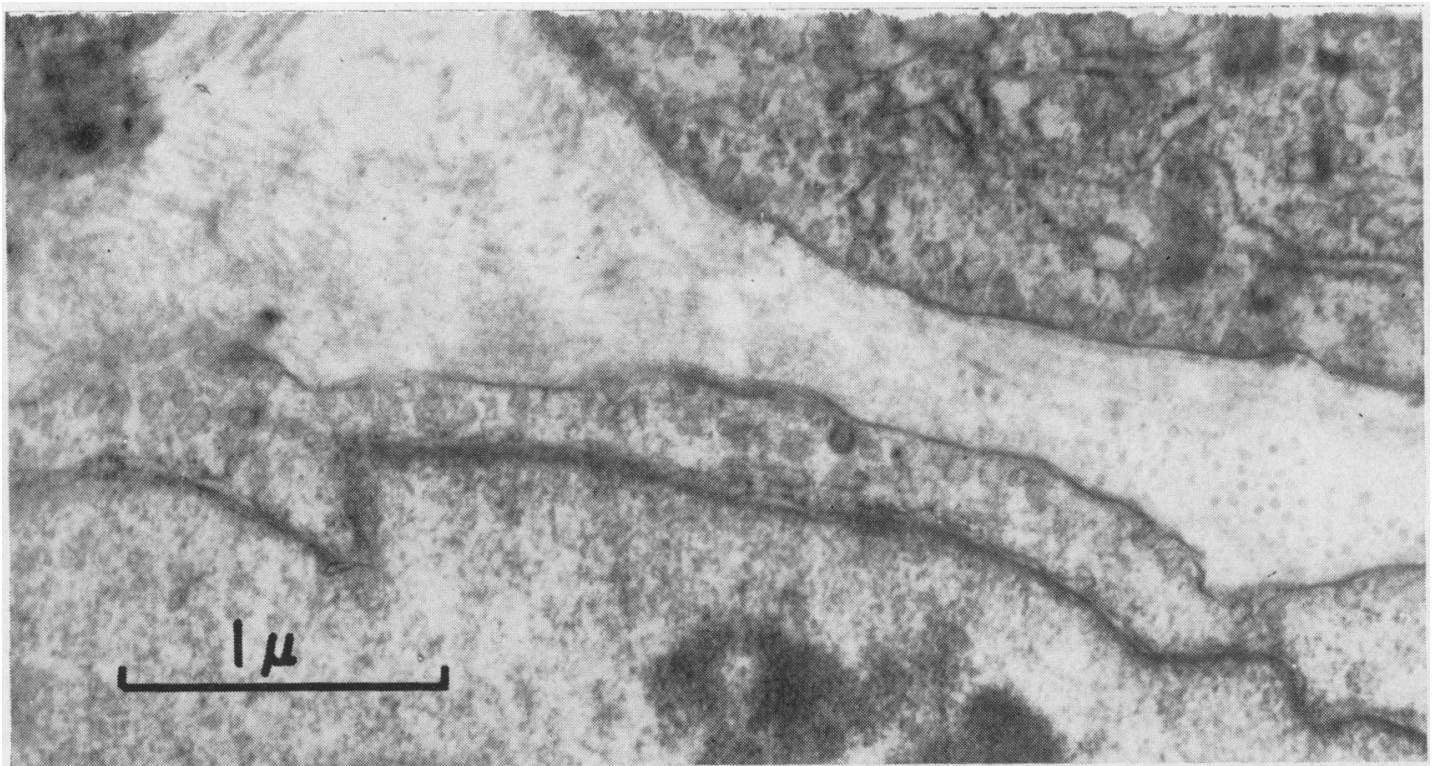

Fig. 9.-Aperiodic fragmented fibres with indistinct outlines lying between synovial cells in the middle zone. $\times 32,000$.

the periodic ones. They also appear to be fragmented and have indistinct outlines (Figs 9 and 10).

Fig. 10.-Comparing the deep and middle zones of synovial matrix. Note banded collagen $(C)$ in deep zone and the much thinner and shorter aperiodic fibres (P) in middle

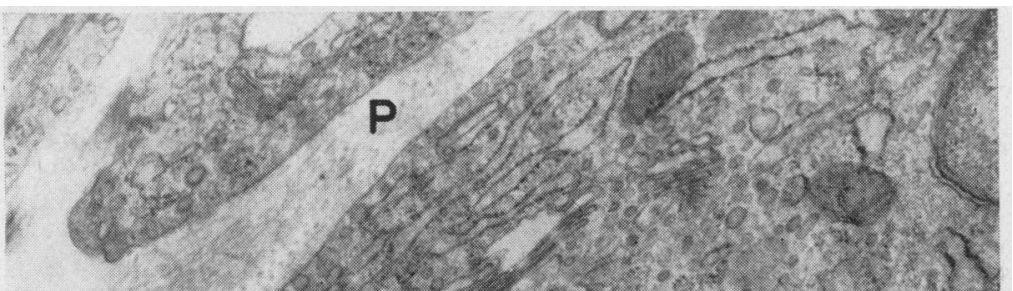
and shorter aperiodic fibres

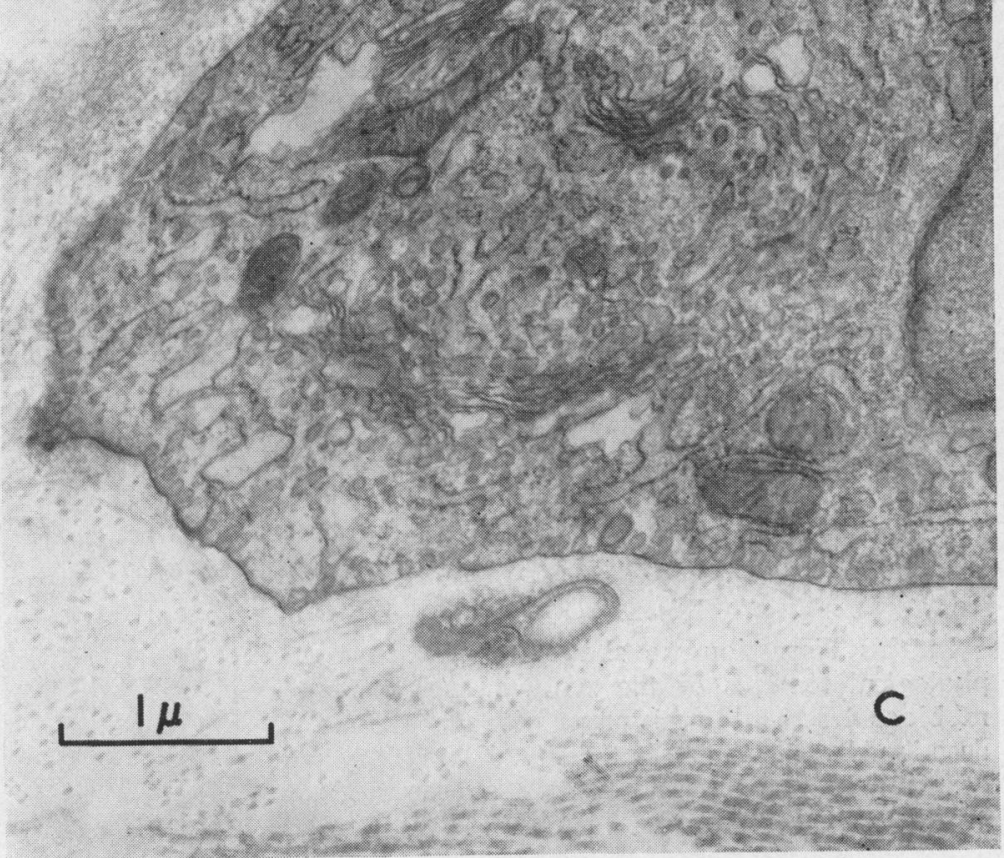




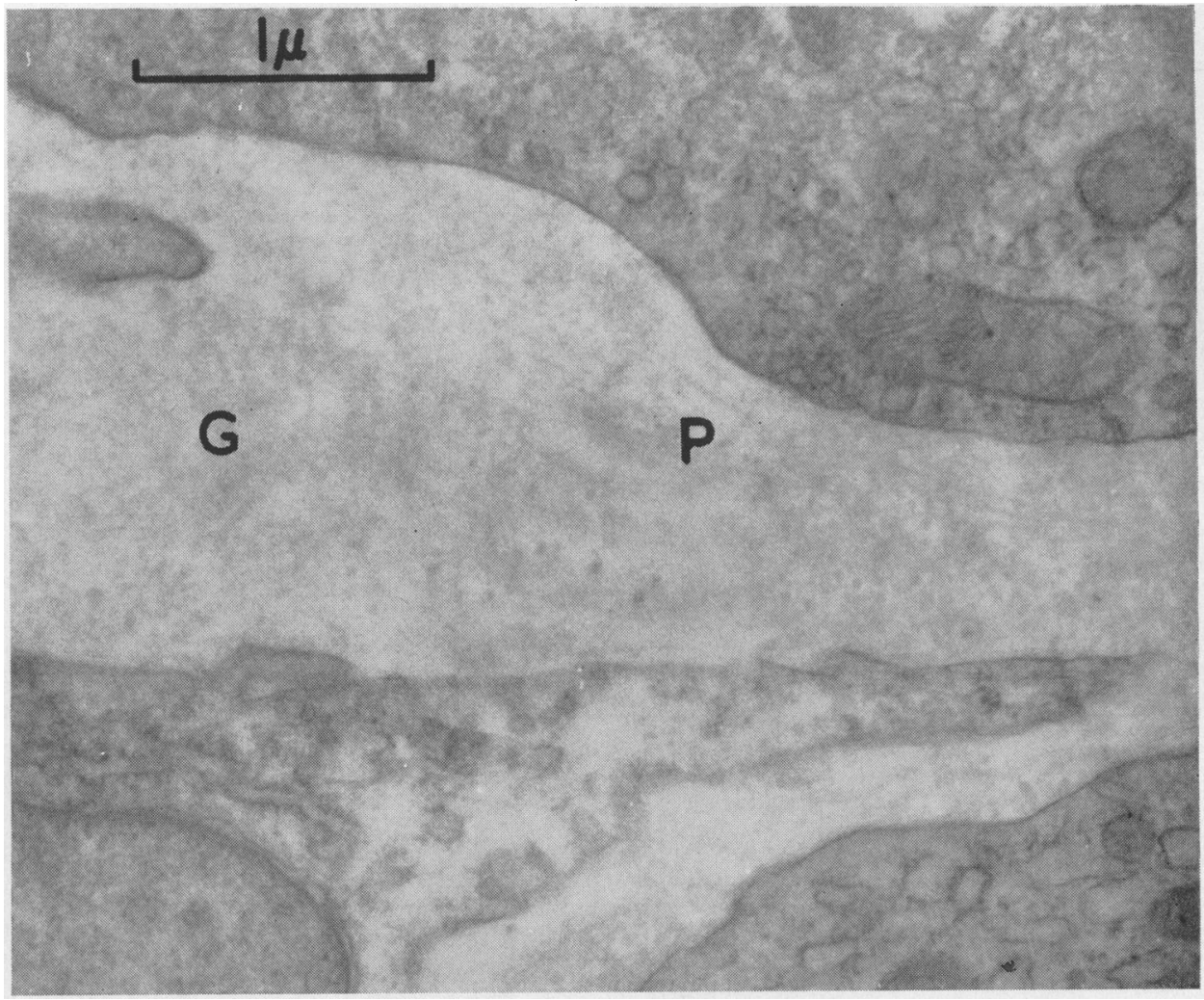
Fig. 11.-Superficial zone of synovial matrix, showing very attenuated,
indistinct aperiodic fibres (P) and granular material (G). $\times 32,000$.

The superficial regions of the matrix contain much granular material and also some very attenuated aperiodic fibres (Fig. 11).

Blood Vessels. - The synovium is richly endowed with capillaries. Most of them lie in the deeper layers of the synovium but an occasional one comes very close to the surface. Fig. 12 shows such a vessel which is separated from the joint space by two attenuated cell processes and a little matrix.

\section{Discussion}

In this discussion we shall compare the morphological features of the synovial membrane of rabbit as described in this paper with that of man as described by Barland and others (1962) and Roy and others (1966) and of guinea-pig as reported by Wyllie and others (1964).

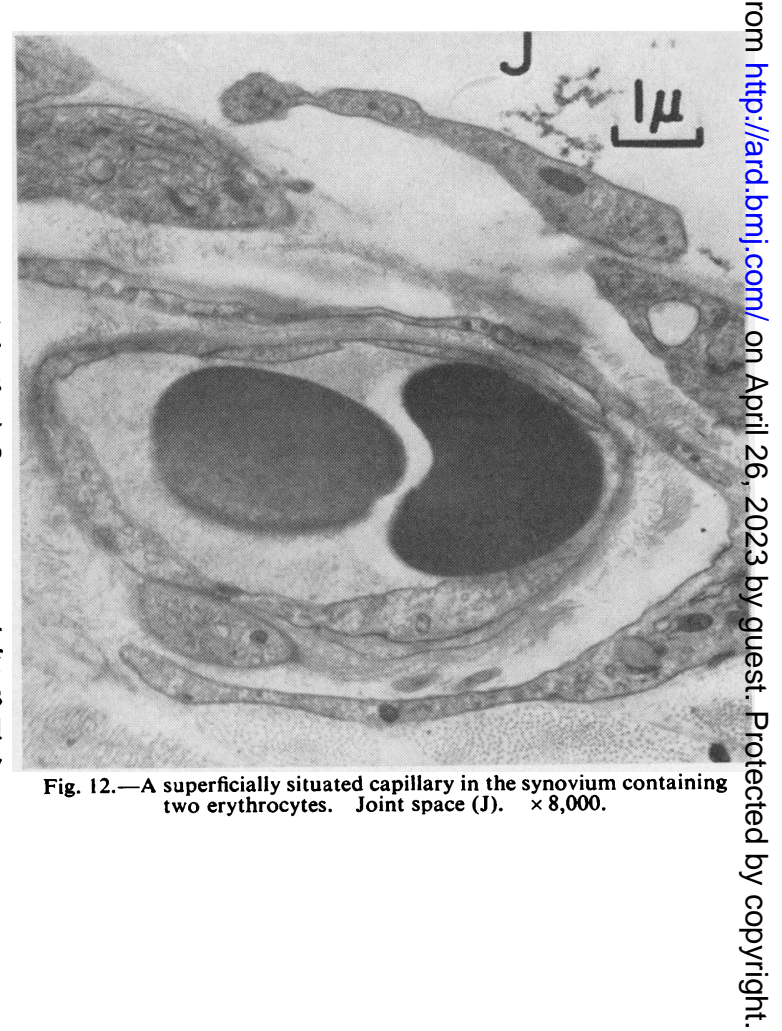




\section{General Architecture and Matrix}

It is now obvious that in all these species the synovial cells are loosely arranged and the electron microscopic appearances in the rabbit further suggest that not only the synovial cells but the matrix may also be exposed at the joint surface (Figs 1 and 2). Whether this is in fact so during life is difficult to assess, for shrinkage due to fixation and processing may well produce such an appearance. The absence of any firm junction between adjacent cells is not very helpful for it could support either hypothesis.

The appearance of the matrix suggests that it too is subject to wear and replacement as are the synovial cells. In the rabbit numerous periodically banded collagen fibres are found in the deeper layers. These are largely replaced by slightly thinner apparently fragmented aperiodic fibres in the mid-zonal region, while the superficial zone contains much granular material. These appearances are suggestive of a gradual disintegration of banded collagen to form first the aperiodic fibres and later the granular material seen in the superficial matrix.

In view of this it is interesting to note that, in man, banded collagen has so far been detected only in the depths of the synovium but never between the synovial cells proper. In the guinea-pig the distribution of periodic and aperiodic fibres appears to be similar to that in the rabbit.

Cell Type.-Recent electron microscopic studies (Barland and others, 1962; Roy and others, 1966) of the synovial membrane of man seem to indicate that two types of cell are present. Type A cells contain numerous vacuoles and micropinocytic vesicles, many filopodia, mitochondria, and prominent Golgi apparatus but very scanty R.E.R., while Type B cells contain a well-developed R.E.R. but only a few mitochondria and pinocytic vesicles and poorlydeveloped Golgi system. Type B cells are less numerous than Type $A$ cells in normal human synovium.

Broadly speaking these cell types are also seen in the guinea-pig and rabbit, but certain differences have been noted. It would appear that filopodia are more prominent and frequent in man than in guineapig and rabbit. Further, we have found that pinocytic vesicles occur more frequently in Type B than in Type A cells. This is in contrast to the findings in man and guinea-pig, where the converse appears to be the case.

Besides these two distinct types of cells, many cells with features of both types were also seen. These intermediate forms contain both prominent Golgi and abundant R.E.R. sometimes having also many pinocytic vesicles. These cells have been noted by us in the human synovium and their presence suggests that they are merely functional variants of the same cell.

\section{Summary}

Two types of cells can be detected in the normal rabbit synovium. Type $A$ is characterized by a prominent Golgi system, while Type B contains abundant rough endoplasmic reticulum. Many intermediate forms, showing both these features were also present. These cells are loosely arranged in a medium density matrix. In deeper zones of the synovium, the matrix contains mainly periodic- $\stackrel{\vec{\omega}}{\omega}$ ally banded collagen fibres; in the middle zone it $\vec{\infty}$ contains mainly aperiodic fibres, and in the superficial zone it contains granular material. It is concluded that, like the synovial cells, the matrix is subject to wear and replacement and that the appearances seen suggest a breakdown of collagen $\vec{v}$ fibres first to aperiodic fibres and then to granular $\mathscr{D}$ material during this process.

This work was supported by a grant from the Arthritis and Rheumatism Council, and was carried out with the technical assistance of Mr. I. F. Coombe, Miss Ann Malone, and Mr. I. Vardey.

\section{REFERENCES}

Ball, J., Chapman, J. A., and Muirden, K. D. (1964). J. Cell Biol., 22, 351.

Barland, P., Novikoff, A. B., and Hamerman, D. (1962). Ibid., 14, 207.

Cochrane, W., Davies, D. V., and Palfrey, A. J. (1965). Ann. rheum. Dis., 24, 2.

Coulter, W. H. (1962). Arthr. and Rheum., 5, 70.

Glauert, A. M. (1961). In "Techniques for Electron Microscopy", ed. D. Kay, pp. 179-181. Black- $\omega$ well, Oxford.

Palade, G. E. (1952). J. exp. Med., 95, 285.

Reynolds, E. S. (1963). J. Cell Biol., 17, 208.

Roy, S., Ghadially, F. N., and Crane, W. A. J. (1966). Ann. rheum. Dis., 25, 259.

Wyllie, J. C., More, R. H., and Haust, M. D. (1964). Lab. Invest., 13, 1254. 


\section{L'ultra-structure de la membrane synoviale du lapin}

\section{RÉSUMÉ}

On peut déceler deux types de cellules dans la synoviale normale du lapin. Le type A se caractérise par un appareil de Golgi proéminent, tandis que le type B contient en abondance un grossier réseau endoplasmique. On trouve aussi beaucoup de formes intermédiaires manifestant les deux particularités. Ces cellules sont lâchement disposées dans une matrice à densité moyenne. Dans les zones plus profondes de la synoviale la matrice contient surtout des fibres collagènes liées périodiquement; dans la zone moyenne elle contient avant tout des fibres apériodiques et dans la zone superficielle un matériel granulaire. On conclut que, comme les cellules synoviales, la matrice subit l'usure suivie de remplacement et que l'aspect observé indique une dégradation des fibres collagènes qui deviennent apériodiques et se transforment éventuellement en matériel granulaire.
La ultrastructura de la membrana sinovial del conejo

Sumario

Se pueden evidenciar dos tipos de células en la sinovia. normal del conejo. El tipo A se caracteriza por un sistema de Golgi destacado, mientras que el tipo B contiene en abundancia un retículo endoplásmico grosero. Se encuentran también muchas formas intermedias mani-음 festando ambas particularidades. Estas células se venç flojamente dispuestas en una matriz de densidad media.币 En las zonas más profundas de la sinovia, la matriz contiene principalmente fibras colágenas agavilladas periodię camente; en la zona media predominan fibras aperíodicas y en la zona superficial se halla un material granula. Se concluye que la matriz, como las células sinoviales, se ve $\overrightarrow{-}$ sometida a un proceso de deterioro y de renovación y quew el cuadio observado indica una degradación de las fibras colágenas que se vuelven aperíodicas y se transforman luego en un material granular. 